University of Nebraska - Lincoln

DigitalCommons@University of Nebraska - Lincoln

$12-2003$

\title{
Impact of firm performance expectations on CEO turnover and replacement decisions
}

\author{
Kathleen A. Farrell \\ University of Nebraska Lincoln, kfarrell2@unl.edu \\ David A. Whidbee \\ Washington State University, dwhidbee@mail.wsu.edu
}

Follow this and additional works at: https://digitalcommons.unl.edu/financefacpub

Part of the Finance and Financial Management Commons

Farrell, Kathleen A. and Whidbee, David A., "Impact of firm performance expectations on CEO turnover and replacement decisions" (2003). Finance Department Faculty Publications. 17.

https://digitalcommons.unl.edu/financefacpub/17

This Article is brought to you for free and open access by the Finance Department at DigitalCommons@University of Nebraska - Lincoln. It has been accepted for inclusion in Finance Department Faculty Publications by an authorized administrator of DigitalCommons@University of Nebraska - Lincoln. 
Published in Journal of Accounting and Economics 36:1-3 (December 2003), pp. 165-196; doi: 10.1016/j.jacceco.2003.09.001 Copyright ( 2003 Elsevier B.V.

Used by permission.

Submitted February 27, 2002; revised September 12, 2003;

accepted September 19, 2003; published online December 9, 2003.

\title{
Impact of firm performance expectations on CEO turnover and replacement decisions
}

\author{
Kathleen A. Farrell \\ Department of Finance, University of Nebraska-Lincoln, \\ Lincoln, NE 68588-0490, USA. \\ Corresponding author - tel 402 472-3005, fax 402 472-5140, \\ email kfarrell2@unl.edu
}

\section{David A. Whidbee}

Department of Finance, Insurance and Real Estate, Washington State University, Pullman, WA 99164-4746, USA

\begin{abstract}
Our analysis suggests that boards focus on deviation from expected performance, rather than performance alone, in making the CEO turnover decision, especially when there is agreement (less dispersion) among analysts about the firm's earnings forecast or there are a large number of analysts following the firm. In addition, our results suggest that boards are more likely to appoint a CEO that will change firm policies and strategies (i.e., an outsider) when forecasted 5-year EPS growth is low and there is greater uncertainty (more dispersion) among analysts about the firm's long-term forecasts.
\end{abstract}

Keywords: CEO turnover, analyst forecasts, earnings announcements

We thank Dae-Lyong Kim, Dandan Wu and Shane McNichols for their research assistance. We appreciate the helpful comments and suggestions of James Brickley (the discussant), John Core, Michelle Hanlon, David Larcker, Chul Park, Robert Parrino (the referee), Rick Sias, Jerold Zimmerman (the editor) and seminar participants at the 2002 JAE Conference on Current Issues in Financial Reporting, Disclosure Practices and Corporate Governance. David Whidbee appreciates the financial support provided by the Brinson Summer Fellowship Program. Kathleen Farrell appreciates receiving support from the 2000 Hicks Foundation Summer Research Grant. 


\section{Introduction}

Empirical evidence suggests there is an increased likelihood of CEO turnover following poor firm performance (e.g., Coughlan and Schmidt ,1985; Warner et al.,1988; Weisbach, 1988; Parrino, 1997). Evidence also indicates that CEOs are often blamed for poor firm performance even when their decisions are similar to the decisions made by the CEOs of comparable firms (e.g., Khanna and Poulsen, 1995; Farrell and Whidbee, 2002). Studies that consider the replacement decision find that the board is more likely to appoint an outsider if the CEO turnover follows a period of poor firm performance (e.g., Parrino, 1997).

We examine CEO turnover and replacement decisions from a different perspective by examining the role of performance expectations. Similar to Puffer and Weintrop (1991), we argue that 1-year analyst forecast errors (the deviation of realized earnings from expected earnings) provide additional information regarding a CEO's performance beyond simple earnings. ${ }^{1}$ To the extent that earnings forecasts proxy for the board of director's earnings expectations, forecast errors may capture the component of firm performance that the board attributes, in large part, to CEO performance. Thus, we hypothesize that, controlling for overall firm performance (e.g., return on assets (ROA) and stock returns), there will be a negative relation between forecast errors and CEO turnover. Moreover, we hypothesize that the relation between forecast errors and CEO turnover is stronger when the forecast error is more unexpected. We argue that a large negative forecast error is more unexpected when there was consensus among analysts (low dispersion) regarding the forecast. Specifically, we expect to observe a stronger relation between forecast errors and CEO turnover when the dispersion in the forecast is low.

We also propose that analysts' earnings growth forecasts proxy for the market's and board's assessment of a firm's policies and strategies. Unlike historic performance measures (e.g., ROA) that likely reflect both the success of the firm's policies and strategies and the CEO's implementation of those policies and strategies, forecasted earnings growth should capture, to a greater degree, the former. As a result, we hypothesize that, controlling for historical performance, the board will be more likely to appoint an outsider (who will be more likely to break with the failed policies and strategies of his/her predecessor) when earnings growth forecasts are low. Again, we hypothesize the relation between forecasted earnings growth and the CEO replacement decision will be stronger when there is less uncertainty regarding the growth forecast.

Utilizing a sample of 4,015 firm-year observations that include 363 CEO turnovers during the 1986-1997 period, we find an inverse relation between the likelihood of CEO turnover and industry-adjusted 1-year analyst forecast errors. These

1 Puffer and Weintrop (1991) find an increased likelihood of CEO turnover when realized earnings fall short of analysts' expectations. However, their study does not distinguish between forced and voluntary turnover nor does it examine the CEO replacement decision. DeFond and Park (1999) and Goyal and Park (2002) also document an inverse relation between the likelihood of CEO turnover and analyst forecast errors. 
results are not sensitive to the inclusion of controls for CEO age, firm size, industry homogeneity, or alternative proxies for firm performance. The results suggest that CEOs are not simply held accountable for the overall level of firm performance, but that boards of directors also use firm performance expectations as part of their criteria for evaluating CEO performance. Further, when industry-adjusted 1-year analyst forecast dispersion is low or the number of analysts following a firm is high, CEOs with negative forecast errors face a greater likelihood of turnover. Again, consistent with our hypothesis, the results suggest that when the signal from the forecast error is more precise (e.g., there is less dispersion) it is accorded more weight in the turnover decision.

Conditional on CEO turnover, we find an inverse relation between industryadjusted 5-year EPS growth rate forecasts and the likelihood that an outsider is appointed CEO, even after controlling for firm size, the tenure of the outgoing CEO, industry homogeneity, the type of turnover (forced vs. voluntary) and multiple measures of firm performance. Counter to our hypothesized relation, the inverse relation between EPS growth rate forecasts and the likelihood that an outsider is appointed CEO is concentrated among those firms that exhibit greater dispersion in analysts' long-term EPS growth rate forecasts. These results suggest that boards appoint outsiders to make changes to firm policies and strategies when a firm's 5-year earnings growth forecast is poor and there is greater uncertainty regarding the forecast. Overall, the implication is that boards of directors are willing to accept the uncertainty associated with an outside replacement CEO when their firm's long-term prospects are both poor and uncertain.

The remainder of this paper is as follows. Section 2 discusses the related literature and develops our hypotheses. Section 3 describes the data. Section 4 tests our predictions about the relation between performance expectations and the CEO turnover and replacement decisions. Section 5 concludes the paper.

\section{Performance expectations and CEO turnover}

\subsection{One-year forecast errors as a measure of CEO performance}

We argue that 1-year analyst forecasts represent a reasonable proxy for the board's expectations of a CEO's performance. Management prepares budgets for the next year that the board approves. The board then holds management responsible for meeting the budget. These budgeted performance standards are likely used in management compensation packages. ${ }^{2}$ To the extent that analyst earnings forecasts are a proxy for information used by boards, forecast errors are likely to capture information about unexpected performance that the board attributes, in large part, to CEO performance.

2 DeFond et al. (2002) argue that 1-year analyst forecasts capture information about expected performance that is used in CEO compensation plans. 
We recognize, however, that analyst forecasts are an imperfect proxy for board expectations and forecasts also capture a CEO's ability to manage expectations. Farrell and Whidbee (2002) argue that one of the CEOs responsibilities is to influence the public's perception of the firm by influencing media coverage. They find evidence that increased scrutiny of poor firm performance by the financial press increases the likelihood of CEO turnover. Extending this argument suggests that a primary responsibility of the CEO is to manage analyst earnings expectations. ${ }^{3}$

Evidence suggests that CEOs have incentives to both manage earnings and also manage earnings expectations. For example, Bartov et al. (2002) find evidence that firms are becoming more successful in meeting or beating analyst earnings expectations in part due to firms managing analyst earnings expectations. ${ }^{4}$ Kasznik and Lev (1995) and Soffer et al. (2000) find evidence that management disclosure strategies regarding earnings announcements are consistent with managers attempting to manage analyst earnings expectations. Recent evidence suggests that CEOs attempt to manage analyst earnings expectations and managers who are better able to manage expectations realize economic benefits through larger bonuses (Matsunaga and Park, 2001) and higher stock option compensation values (Aboody and Kasznik, 2000). ${ }^{5}$

Although the expectations management literature suggests that analyst earnings forecasts may differ from the board's expectations, we argue that any deviation of analyst forecasts from board expectations is due, in part, to the CEO's inability to effectively manage analyst expectations or to the CEO's inability to effectively manage the real assets of the firm. To the extent that the board views both roles as important in determining CEO performance, however, we would expect forecast errors to provide additional information regarding CEO performance beyond other measures of firm performance that include both expected earnings and unexpected earnings (e.g., ROA and stock returns).

In addition to capturing CEO performance, analyst forecast errors also capture the impact of unanticipated events on firm performance. By using industryadjusted forecast errors in our analysis, we attempt to control for industry-wide events that affect performance. Previous research on CEO turnover decisions provides evidence suggesting that relative performance evaluation is utilized in retention decisions (e.g., Barro and Barro, 1990; Blackwell et al., 1994). Therefore, our first hypothesis predicts that there will be an inverse relation between the likelihood of CEO turnover and industry-adjusted analyst forecast errors and

3 Expectations management is consistent with the management literature regarding impressions management, which includes the idea that top management is expected to not only manage a firm's performance but also the perceptions of the firm's performance (e.g., Ginzel et al., 1992).

4 Other studies analyze earnings management as a means to meet analyst earnings forecasts (e.g., Kasznik, 1999; Payne and Robb, 2000). Earnings management and expectations management are non-mutually exclusive explanations for meeting or beating analyst earnings expectations. See Healy and Wahlen (1999) for a review of the earnings management literature.

5 Managers also have the incentive to reduce negative forecast errors to avoid legal actions by shareholders (Kasznik, 1999; Skinner, 1997). 
that analyst forecast errors have explanatory power beyond alternative firm performance proxies such as ROA and stock returns.

Although we suggest that CEOs are held responsible for some expected level of performance, analyst forecasts may be a poor proxy for CEO performance expectations if the level of uncertainty associated with the firm's original earnings forecast was high. For example, earnings expectations may be a poor proxy for CEO performance standards in firms that are facing a crisis (e.g., financial distress, a labor dispute, legal or regulatory action, or hostile takeover attempt) or that have substantial information asymmetry. For these firms, CEOs may be evaluated more on their ability to manage the firm through the crisis or board members may have performance expectations that differ substantially from analyst expectations.

Previous research suggests that the usefulness of a performance measure in a compensation contract is related to the extent to which it contains information about the CEO's actions. According to this literature, a performance measure with a greater "signal-to-noise" ratio will receive a greater weight in the CEO's compensation contract (e.g., Holmstrom, 1979). Lambert and Larcker (1987) and Sloan (1993), among others, provide evidence suggesting that optimal compensation contracts place less reliance on performance measures when they contain considerable noise. Engel et al. (2002) make a similar argument concerning the CEO turnover decision. We extend this argument to suggest that the uncertainty associated with earnings forecasts impacts the degree to which boards hold CEOs accountable for firm performance expectations in the CEO turnover decision. ${ }^{6}$ We expect earnings forecasts to be accorded less weight in the turnover decision when there is more uncertainty associated with the forecasts.

Therefore, our second hypothesis is that the association between the likelihood of CEO turnover and analysts' forecast errors is inversely related to analyst forecast dispersion. We measure the dispersion in analyst forecasts as the standard deviation of the EPS forecast at the beginning of the fiscal year divided by the absolute value of the consensus EPS forecast at the beginning of the fiscal year (similar to DeFond et al., 2002). ${ }^{7}$ Given the evidence that board members filter out industry effects in performance measures when making the CEO turnover decision (e.g., Weisbach, 1988; Parrino, 1997; DeFond and Park, 1999), we also expect board members to filter out industry effects in the uncertainty associated with firm performance. Further, some industries may tend to place more emphasis on performance expectations than other industries when evaluating CEO performance. Alternatively, board members may be concerned with the overall uncertainty associated with a firm's earnings forecast. To allow for all these possibilities, we decompose the dispersion measure into its industry and firm-specific (or

6 DeFond et al. (2002) find evidence that directors rely less on expected earnings in constructing CEO performance standards for compensation contracts when analyst earnings forecast dispersion increases.

7 Lambert and Larcker (1987) measure relative noise by computing the ratio of the historical standard deviation in ROA and the historical standard deviation in stock returns. Engel et al. (2002) use the ratio of the industry-adjusted variance of earnings divided by the industry-adjusted variance of monthly stock returns. 
industry-adjusted) components to test empirically whether total uncertainty, industry uncertainty, or firm-specific uncertainty affects the relation between analyst forecast errors and CEO turnover. ${ }^{8}$

\subsection{Five-year EPS growth rate forecasts as an assessment of firm policies and strategies}

Analysts' long-term EPS growth rate forecasts attempt to capture the longterm earnings potential for the firm based on the firm's expected future growth opportunities. Unlike measures of past performance, these long-term forecasts are for a 5-year period in the future and tend to correspond with the typical horizon used in management strategic planning. We argue that analysts' earnings growth rate forecasts are a reasonable proxy for the market's and board's assessment of a firm's policies and strategies. Since long-term planning may extend beyond a current CEO's tenure, long-term forecasts implicitly capture analysts' expectations associated with the policies and strategies of the firm as opposed to focusing solely on the abilities of the current CEO.

Therefore, our third hypothesis predicts a negative relation between 5-year EPS growth rate forecasts and the likelihood of an outside replacement. ${ }^{9}$ If a firm has sound policies and strategies in place, then its earnings growth prospects will be high relative to other firms in its industry, the need to change course will be lower, and the attractiveness of internal candidates in the CEO replacement decision will be higher. Firms with high growth prospects will be less likely to hire from outside the firm and more likely to promote from within. By examining whether expectations of future earnings growth have a greater impact on the CEO replacement decision than past performance, we test whether corporate boards distinguish between the performance of the outgoing CEO and the soundness of firm policies and strategies.

To the extent that the dispersion in 5-year EPS growth rate forecasts captures disagreement among analysts (and board members) regarding a firm's future earnings prospects, we would expect greater dispersion to be associated with more uncertainty regarding the soundness of the firm's policies and strategies. With greater disagreement regarding the soundness of the policies and strategies, we would expect a weaker relation between the consensus earnings growth forecasts and the board's CEO replacement decision. If, on the other hand, there is consensus among analysts (and board members) regarding earnings growth forecasts, then we would expect those forecasts to represent a more certain assessment of the firm's policies and strategies and have a significant impact on the CEO replacement decision.

8 Our analysis differs from Lambert and Larcker (1987), Sloan (1993), and Engel et al. (2002) since these studies focus on the relative use of stock returns vs. earnings in compensation contracts or turnover decisions while our study examines the extent to which performance expectations affect the turnover decision.

9 This prediction is consistent with the positive abnormal return associated with the announcement of an outside replacement following forced CEO turnover documented by Borokhovich et al. (1996). 
Therefore, our fourth hypothesis predicts a weaker relation between the 5year EPS growth rate forecast and outside CEO replacement when the dispersion in the 5-year EPS growth rate forecast is high. As in our test of hypothesis two, we measure the dispersion in the 5-year EPS growth rate forecast as the standard deviation of the forecast at the beginning of the fiscal year divided by the absolute value of the consensus forecast at the beginning of the fiscal year. As in our specification of hypothesis two, we also decompose this dispersion measure into its industry and firm-specific (or industry-adjusted) components.

Based on the four hypotheses outlined above, our analysis allows us to comment on the extent to which the CEO turnover and replacement decisions of corporate boards are a reaction to poor performance and/or proactive attempts to improve firm policies and strategies.

\section{Data and summary statistics}

The sample of firms used in this study includes all firms in unregulated industries that satisfy the following criteria:

1. The firm is included in the Execucomp database during the 1993-1997 period or appears in the Forbes Annual Survey of Compensation in the 1985-1992 period. ${ }^{10}$

2. Any CEO turnovers are announced in the Wall Street Journal with age and tenure data available for the outgoing CEO and incoming CEO in proxy statements, Forbes, the Reference Book of Corporate Management, or the Million Dollar Directory.

3. Financial statement data are available on the Compustat database and return data are available on the CRSP database.

4. Analyst forecast data are available on the Zacks Investment Research database. ${ }^{11}$

We identified 363 turnovers in 4,015 firm years for 526 firms based on the above criteria. ${ }^{12}$ Outsiders, defined as a new CEO that joins the firm no more than 1 year prior to the turnover announcement, were appointed to the CEO position in 83 of the 363 turnovers.

10 Murphy and Zimmerman (1993) note that sample selections based on the Forbes 500 tend to bias a sample toward large, surviving, and growing firms. When possible, we include firms that drop out of the Forbes sample before the end of the 1992 period, as well as firms that appear in Forbes at any time during the sample period. Our turnover sample period ends in 1997 because we gathered analyst forecast data 2 years beyond the turnover date and the analyst data available to us was limited to forecasts made through 1999.

11 We excluded a firm-year observation from the sample if it did not have at least three analyst forecasts of 1-year EPS and 5-year EPS growth rates at the beginning of the fiscal year. Although necessary for our analysis, this further biases the sample toward larger firms.

12 Of the 526 firms in the sample, 254 experience no turnover, 199 experience one turnover, and 73 experience multiple turnovers. 


\subsection{Classifying forced vs. voluntary CEO turnovers and inside vs. outside replacements}

Our scheme for classifying turnovers as forced or voluntary is based on those of Weisbach (1988), Gilson (1989), and Parrino (1997) and incorporates elements of each. We classify as forced turnovers all CEO changes other than those arising from retirement, normal management succession, death, illness, or those involving the CEO's departure for a prestigious position elsewhere. We initially assume a voluntary retirement for any departing CEO at least 64 years old unless we later uncover information suggesting the departure is performance-related.

We consult the Wall Street Journal (WSJ), Wall Street Journal Index (WSJI), or both for turnover reasons. First, we checked the WSJI, which in some cases provides an unambiguous reason for the CEO's departure. If, however, the WSJI-reason is unclear or if no reason is mentioned, we consult the full WSJ article. We also consult the full article for reported retirements, resignations, or normal management successions to determine whether these reasons are related to poor firm performance. Although we attempt to carefully identify forced and voluntary turnover, firms may not report a precise reason for the turnover (e.g., Warner et al., 1988; Weisbach, 1988) and rarely cite poor management performance as an explanation of a CEO change (DeFond and Park, 1999). As a result, there may be error in our classification of forced and voluntary turnover. To control for this potential misclassification, we include a dummy variable for CEO age in our model as noted in Section 3.3.

As depicted in Table 1, voluntary turnovers account for approximately 76.3 percent of the turnovers in the sample or about seven percent of the sample observations. About 23.7 percent of turnovers or 2.1 percent of the sample observations are forced. ${ }^{13}$ We classify the new CEO as an outside replacement if he/she joined the firm less than 1 year before the CEO turnover announcement. All other new CEOs are classified as inside replacements. The most common type of turnover in Table 1 is a voluntary turnover followed by an inside replacement (64.7 percent of turnovers or 5.9 percent of sample observations) and then a forced turnover followed by an inside replacement (12.4 percent of turnovers or 1.1 percent of sample observations). Approximately 11.3 percent of turnovers are forced turnovers followed by outside replacements and 11.6 percent are voluntary turnovers followed by outside replacements. In our sample, the incoming CEO is almost equally likely to be an insider or outsider when following a forced turnover. ${ }^{14}$ However, of the 277 voluntary turnovers, 235 replacement CEOs are insiders ( 84.8 percent).

Similar to the trend documented in Huson et al. (2001), Table 1 shows that both forced turnovers and outside replacements have become more common in the lat-

13 For comparison, Huson et al. (2001) define 20 percent of their CEO turnovers as forced over the sample period 1983-1994 but document a higher incidence of forced turnover (23.4 percent) in the last sub-sample period in their study (1989-1994). Over the sample period 1984-1988, Denis and Denis (1995) classify between 18 and 21 percent of top executive changes as forced depending on the data restrictions applied.

14 For comparison, Denis and Denis (1995) document 57.1 percent and Huson et al. (2001) document 53.5 percent of forced turnovers as being followed by outside replacements. 
Table I. CEO turnovers and non-turnover observations by year ${ }^{\mathrm{a}}$

\begin{tabular}{|c|c|c|c|c|c|}
\hline \multirow[b]{2}{*}{ Fiscal year } & \multicolumn{2}{|c|}{ Forced turnovers } & \multicolumn{2}{|c|}{ Voluntary turnovers } & \multirow[t]{2}{*}{ No turnover } \\
\hline & $\begin{array}{l}\text { Outside } \\
\text { replacement }\end{array}$ & $\begin{array}{l}\text { Inside } \\
\text { replacement }\end{array}$ & $\begin{array}{l}\text { Outside } \\
\text { replacement }\end{array}$ & $\begin{array}{l}\text { Inside } \\
\text { replacement }\end{array}$ & \\
\hline 1986 & I (0.7\%) & $2(1.4 \%)$ & $0(0.0 \%)$ & 17 (I2.1\%) & 120 (85.7\%) \\
\hline 1987 & $3(1.2 \%)$ & $6(2.4 \%)$ & I (0.4\%) & $16(6.5 \%)$ & $220(89.4 \%)$ \\
\hline 1988 & 3 (I.I\%) & I (0.4\%) & $0(0.0 \%)$ & $29(10.1 \%)$ & $253(88.5 \%)$ \\
\hline 1989 & $2(0.7 \%)$ & $3(1.0 \%)$ & $0(0.0 \%)$ & $23(7.6 \%)$ & 276 (90.8\%) \\
\hline 1990 & $3(1.0 \%)$ & $6(1.9 \%)$ & $2(0.6 \%)$ & $24(7.6 \%)$ & 281 (88.9\%) \\
\hline 1991 & I (0.3\%) & $3(1.0 \%)$ & $5(1.6 \%)$ & 14 (4.6\%) & 285 (92.5\%) \\
\hline 1992 & I (0.3\%) & $4(1.3 \%)$ & I (0.3\%) & $10(3.1 \%)$ & $303(95.0 \%)$ \\
\hline 1993 & 6 (1.8\%) & $6(1.8 \%)$ & $7(2.1 \%)$ & $19(5.7 \%)$ & 296 (88.6\%) \\
\hline 1994 & 4 (I.0\%) & $5(1.2 \%)$ & $6(1.4 \%)$ & $29(7.0 \%)$ & 372 (89.4\%) \\
\hline 1995 & $3(0.7 \%)$ & $2(0.4 \%)$ & $8(1.8 \%)$ & $22(4.9 \%)$ & 415 (92.2\%) \\
\hline 1996 & $10(2.2 \%)$ & $3(0.7 \%)$ & 7 (1.5\%) & 17 (3.7\%) & 420 (91.9\%) \\
\hline 1997 & $4(0.9 \%)$ & $4(0.9 \%)$ & $5(1.1 \%)$ & 15 (3.4\%) & $4 I I(93.6 \%)$ \\
\hline Total & $4 \mathrm{I}(1.0 \%)$ & 45 (1.1\%) & 42 (1.1\%) & 235 (5.9\%) & 3,652 (9l.0\%) \\
\hline
\end{tabular}

This table documents the number and percentage of firm-year observations that are turnovers by type of turnover and whether the replacement CEO is an outsider or insider for each year in the 1986-1997 period for which we have sufficient analyst forecast data.

a Percentages may not sum to $100 \%$ due to rounding.

ter part of the sample period. To control for the general increase in both events, we include year dummy variables in the empirical analysis of both turnovers and outside replacements.

\subsection{EPS forecasts and other performance measures around CEO turnover}

As an initial step toward examining the relation between firm performance expectations and the CEO turnover and replacement decisions, we examine the industry-adjusted median 1-year EPS forecast, forecast errors, 5-year EPS growth rate forecast, and ROA in the years surrounding turnover. Forecast errors are estimated as the deviation of realized EPS from the beginning-of-year forecasted EPS. Following Atiase and Bamber (1994), we scale the 1-year EPS forecast and forecast error by the beginning-of-year stock price to allow for comparability across firms. ${ }^{15}$ All measures are industry adjusted by differencing from industry medians, which are based on two-digit SIC codes.

Figure 1 illustrates the median forecast and performance measures in the years surrounding CEO turnover for the four turnover-replacement type combinations.

15 Our results are robust to scaling by total assets per share. We chose not to compute the forecast error as a percent of the initial forecast because firms may have very small or even negative 1year EPS forecasts. The forecast errors for these firms would be difficult to interpret. In addition, scaling by stock price per share is more likely to capture the economic meaningfulness of the forecast error. 

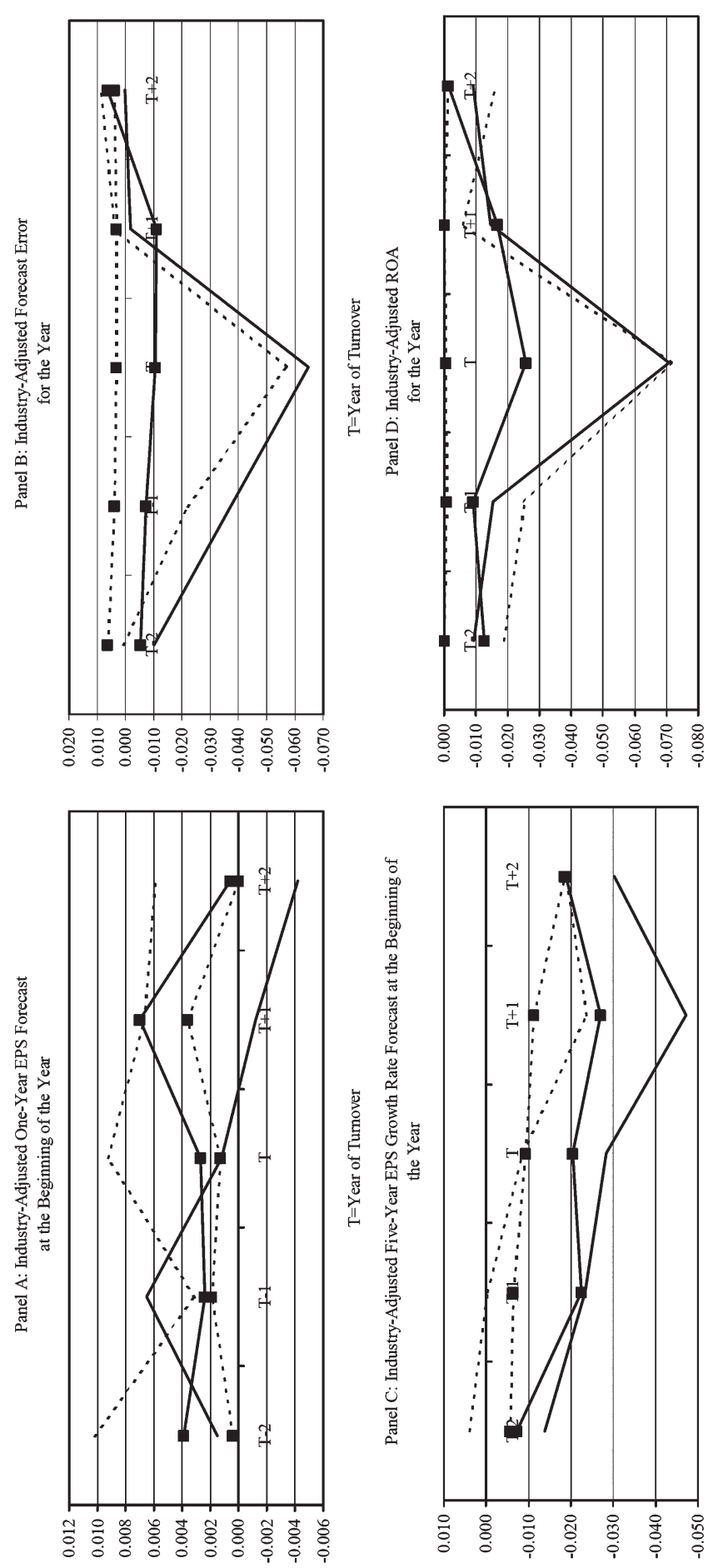

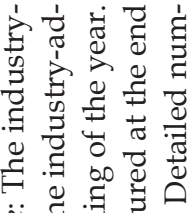

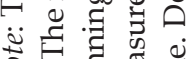
之 ذे $\searrow 0$ ठิ 考范

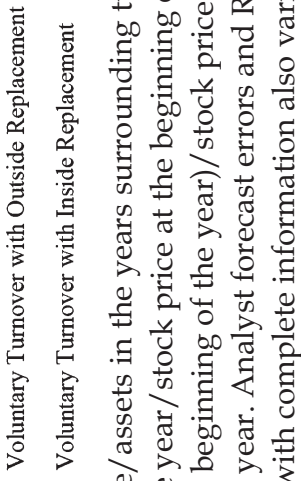

$1:$ : a

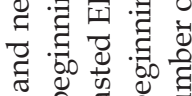
言言

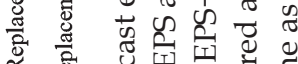
\% :

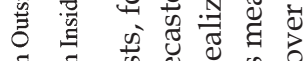
片

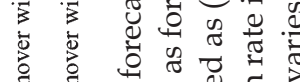

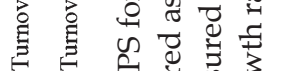
पु

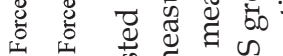

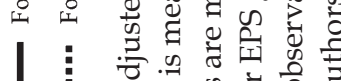

1 का की है द चु

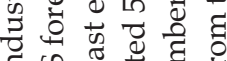
ज㻤 되웡: 름

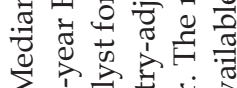
$x^{2}$ - تٓ ฮี

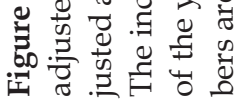


When interpreting the data in Figure 1, note that the 1-year, industry-adjusted EPS forecasts (Panel A) and industry-adjusted 5-year EPS growth forecasts (Panel C) are measured at the beginning of the year and, accordingly, reflect expectations. The industry-adjusted forecast error (Panel B) and industry-adjusted ROA (Panel D), on the other hand, represent realizations as they are measured at the end of the corresponding year.

Figure 1 reveals substantial variation in the four types of succession events across the alternative performance measures. In Panel A, the 1-year, industry-adjusted EPS forecasts for the firms experiencing voluntary turnover with inside replacement are significantly greater than zero in most years, suggesting that these firms are expected to consistently perform better than their industry peers. However, the median industry-adjusted EPS forecasts for the other three turnover categories typically are not significantly different from zero. ${ }^{16}$

Consistent with Puffer and Weintrop (1991), industry-adjusted EPS forecast errors tend to be negative in the year prior to turnover, especially for the firms that experience forced turnovers. This suggests that the likelihood of CEO turnover is inversely related to the difference between realized earnings and earnings forecasts. Puffer and Weintrop (1991) suggest that analysts perform an important monitoring function in which they establish performance benchmarks that managers are expected to meet. Similarly, analyst forecasts may reflect the board's performance expectations. Their results may be due to the board removing senior managers that fail to meet expectations.

In the year of turnover, the median forecast errors are significantly negative for the forced turnovers and the voluntary turnovers with outside replacement in Panel B of Figure 1. In the year prior to turnover, the median forecast errors are significantly negative for the forced turnovers. These negative forecast errors are consistent with the increased likelihood of turnover surrounding poor firm performance and may simply reflect the poor performance of the exiting CEO. Consistent with studies that find significant improvements in firm performance following CEO turnover (e.g., Denis and Denis, 1995), Panel B shows that median forecast errors are no longer negative by the second year after CEO turnover for all turnover types.

The industry-adjusted 5-year EPS growth rate forecasts shown in Panel C of Figure 1 indicate that those firms experiencing an outside replacement also tend to be those with the most pessimistic forecasts. Since it is more difficult for large firms to maintain the same growth rates as small firms and our sample selection criteria biases the sample toward larger firms, it is not surprising that the median industry-adjusted 5-year EPS growth rate forecast at the beginning of the year in which turnover occurs is negative and statistically significant for all turnover categories in Panel C. In the years after turnover, Panel C of Figure 1 suggests little, if any, improvements in the 5-year EPS growth rate forecast. The voluntary turnover firms with inside replacements continue to suffer a decline in their growth

16 In results not shown, we test whether the median figures illustrated in Figure 1 differ significantly from zero using the non-parametric, signed rank statistic. These results are available from the authors. 
rate forecasts. This is consistent with the improvement in forecast errors in the years after turnover for all but the voluntary turnovers with inside replacement.

For comparison purposes, we also include the industry-adjusted ROA in the years surrounding turnover in Panel D of Figure 1. Borokhovich et al. (1996) find that firms with a low EBIT-to-assets ratio in the year prior to turnover are significantly more likely to appoint an outside successor. Panel D shows that the median ROA is negative and statistically significant in the year prior to turnover for the forced-turnover types and the voluntary turnovers with outside replacement. In addition, the median ROA is negative and statistically significant in the year of forced turnover for both inside and outside replacement.

\subsection{Control variables}

In addition to the EPS forecasts and performance measures discussed above, we expect other variables to affect the CEO turnover and replacement decisions. The median and mean of these variables along with the EPS forecast and performance measures are shown in Table 2. For the turnover observations, the variables are measured at the end of the fiscal year prior to the year in which the turnover was announced. For the no turnover observations, Table 2 reports the median and means across all firm-year observations.

To control for the level of uncertainty in earnings estimates, we analyze the effect of the dispersion in analyst forecasts on the likelihood of CEO turnover and the likelihood of an outside replacement. The dispersion in analyst earnings forecasts is measured as the standard deviation of the EPS forecast scaled by the absolute value of the consensus EPS forecast. For descriptive purposes, we report the mean and median of two dispersion measures in Table 2. The first dispersion measure is industry adjusted by differencing from industry medians, which are based on two-digit SIC codes. The second dispersion measure captures total dispersion. In the empirical analysis that follows, we create two dummy variables: a dummy variable that is equal to one if the median dispersion for the firm's industry is greater than the median for all firms, zero otherwise; and a dummy variable that is equal to one if the firm's dispersion measure is greater than the industry median, zero otherwise.

While the dispersion in analyst forecasts measures the level of uncertainty or disagreement in earnings estimates, it may also capture differences in the level of firm complexity not captured by other control variables (e.g., firm size and industry homogeneity). ${ }^{17}$ Therefore, the results concerning the dispersion measures should be interpreted with caution.

Table 2 shows that outside replacements are associated with greater total dispersion and firm-specific dispersion in both 1-year EPS forecasts and 5-year EPS growth rate forecasts, which suggests that boards of directors are more likely to appoint an outside replacement when there is greater uncertainty associated with

17 The correlations between our industry homogeneity measure, the forecast dispersion measures, and firm size are all relatively small. The absolute value of the mean cross-sectional correlations between the various combinations of variables is consistently below 0.10 . 
future earnings prospects. We are unable to draw inferences regarding our second hypothesis that the association between the likelihood of CEO turnover and analysts' forecast errors is inversely related to analyst forecast dispersion from the descriptive statistics since our hypothesis suggests an interaction between the forecast error and forecast dispersion variables. Similarly, our fourth hypothesis suggests an interaction between 5-year EPS growth rate forecasts and the dispersion in the forecast. We revisit these hypotheses in Section 4. As an additional control, we also include a measure of the number of analysts making a 1-year EPS forecast. As noted in Table 2, the median number of analysts for the various categories ranges from 12 to 15 but is not significantly different between firms with inside and outside replacements.

Several studies find a positive relation between the likelihood of CEO turnover and firm size (e.g., Huson et al., 2001). In addition, other studies find that larger firms are more likely to appoint an insider to replace an outgoing CEO (e.g., Parrino, 1997). One potential explanation for this empirical regularity is that smaller firms tend to have fewer senior managers that are qualified to replace the outgoing CEO and an outside candidate is more likely to be effective in a smaller, less complex organization. Following Borokhovich et al. (1996) and Agrawal et al. (2001), we use the natural log of the number of firm employees as a proxy for size. ${ }^{18}$

CEO age is also expected to affect the likelihood of CEO turnover. Table 2 shows CEO age measured two ways. First, we measure the CEO age in years. Second, we measure CEO age using a dummy variable to indicate whether a firm's CEO is older than 60 years of age. The voluntary turnovers that are followed by an inside replacement tend to be the oldest group with a median (mean) age of 64 (63.1) while the forced turnovers that are followed by an outside replacement tend to be the youngest group with a median (mean) age of 55 (55.5). The median and mean of the CEO age dummy variable echo these results. Following Borokhovich et al. (1996) and Parrino (1997), we include the CEO age dummy in the analysis that follows rather than CEO age. The likelihood of forced CEO turnover seems unrelated to CEO age while the likelihood of voluntary turnover seems to increase once a CEO reaches the age of 60 , but does not increase linearly beyond the age of 60 .

When analyzing the choice between an inside vs. outside CEO replacement, the tenure of the outgoing CEO may be important. When an outgoing CEO has been in place for a long time, he or she is more likely to have a designated successor. The outgoing CEO likely has significant influence on the replacement decision because of his or her power over the board (Hermalin and Weisbach, 1998), which arguably increases with tenure. Also, the long tenure may be indicative of the board's favorable assessment of the current direction of the firm. We include the number of years the outgoing CEO has been in office as an independent variable to control for these possibilities. Table 2 indicates that the mean tenure of the outgoing CEO is longer in those firms that appoint an inside CEO as illustrated by CEO tenure of 8.9 and 10.3 years for forced and voluntary turnover with inside replacement, respectively.

18 Alternative proxies for size (log of sales, log of assets, log of market capitalization) yield similar results. 


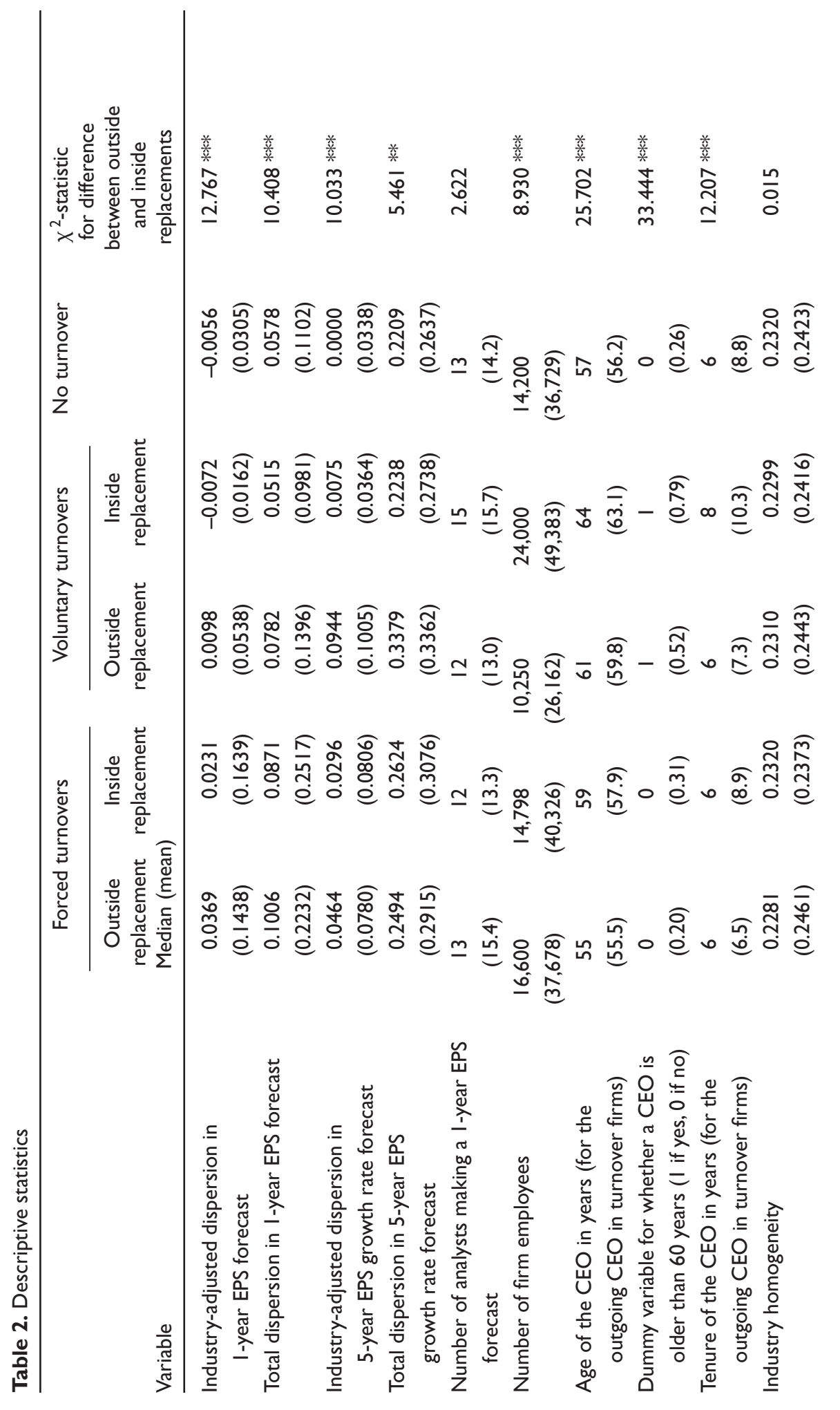




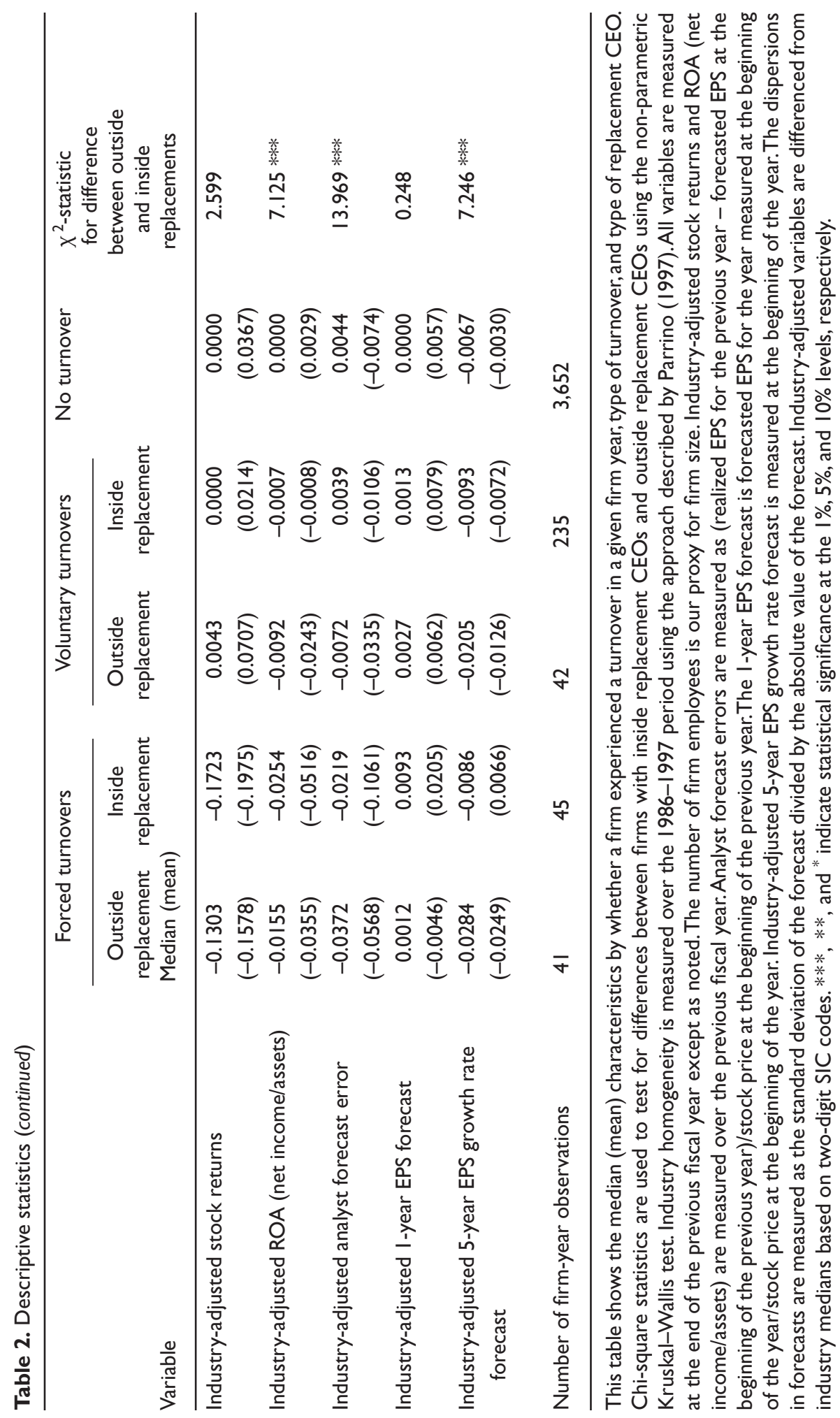


Parrino (1997) finds evidence that CEO turnovers and outside replacements are more likely in homogeneous industries due to the increased availability of strong outside candidates. DeFond and Park (1999) find that the frequency of CEO turnover is greater in highly competitive industries than in less competitive industries. Industry competition and homogeneity are likely to be highly correlated. We include industry homogeneity in our analysis because it has been shown to be important in the replacement decision as well as the turnover decision. Following Parrino, we construct a proxy for industry homogeneity and include this variable in the analysis to control for the availability of an outside candidate on both the CEO turnover and replacement decisions. ${ }^{19}$

Consistent with the evidence shown in Figure 1, Table 2 indicates that the firms experiencing turnover, especially forced turnover, tend to perform worse than those not experiencing turnover regardless of how performance is measured. There is no significant difference in industry-adjusted stock returns, however, between the turnover firms with inside replacements and those with outside replacements. Nevertheless, we include industry-adjusted stock returns in our analyses so that our results are comparable to other studies that include stock returns in their analysis.

\subsection{Correlations between performance and analyst forecast variables}

The preceding analysis suggests that many of the performance measures and analyst forecast variables might be correlated with each other. To assess whether our analysis might suffer from multicollinearity, we examine the mean cross-sectional correlation coefficients between these variables in Table 3.' 20 The mean correlation between ROA and the analyst forecast error is 0.568 , indicating that these two measures of past performance are positively correlated. Neither ROA nor the analyst forecast errors are significantly related to the 1-year EPS forecast. All measures of past performance are positively correlated with the 5-year EPS growth rate forecast while the 1-year EPS forecast and the 5-year

19 First, we estimate a two-factor market model over the 1986-1997 period using monthly returns for up to 50 randomly selected firms from each industry where we exclude those firms that do not have at least 36 months of return data available and those industries that do not have at least 35 firms with sufficient return data. Industries are defined by two-digit SIC codes. The first factor in the regression is the CRSP equally weighted return index for the NYSE, AMEX, and Nasdaq. The second factor is an equally weighted industry return index constructed from the same randomly selected group of firms. Second, we determine the partial correlation coefficient for the industry return index in each individual-company regression. Third, we determine the average of these partial correlation coefficients for each industry. The average partial correlation coefficient for each industry is our proxy for industry homogeneity.

20 We calculate the mean cross-sectional Pearson correlation coefficients for all the performance and analyst forecast variables. The mean correlation coefficients are calculated over the entire sample of firm-year observations, including both the turnover observations and the non-turnover observations. Specifically, we calculate the cross-sectional correlation coefficients for each fiscal year and then analyze the mean of these coefficients. The detailed results regarding correlation coefficients for all independent variables are available from the authors. 


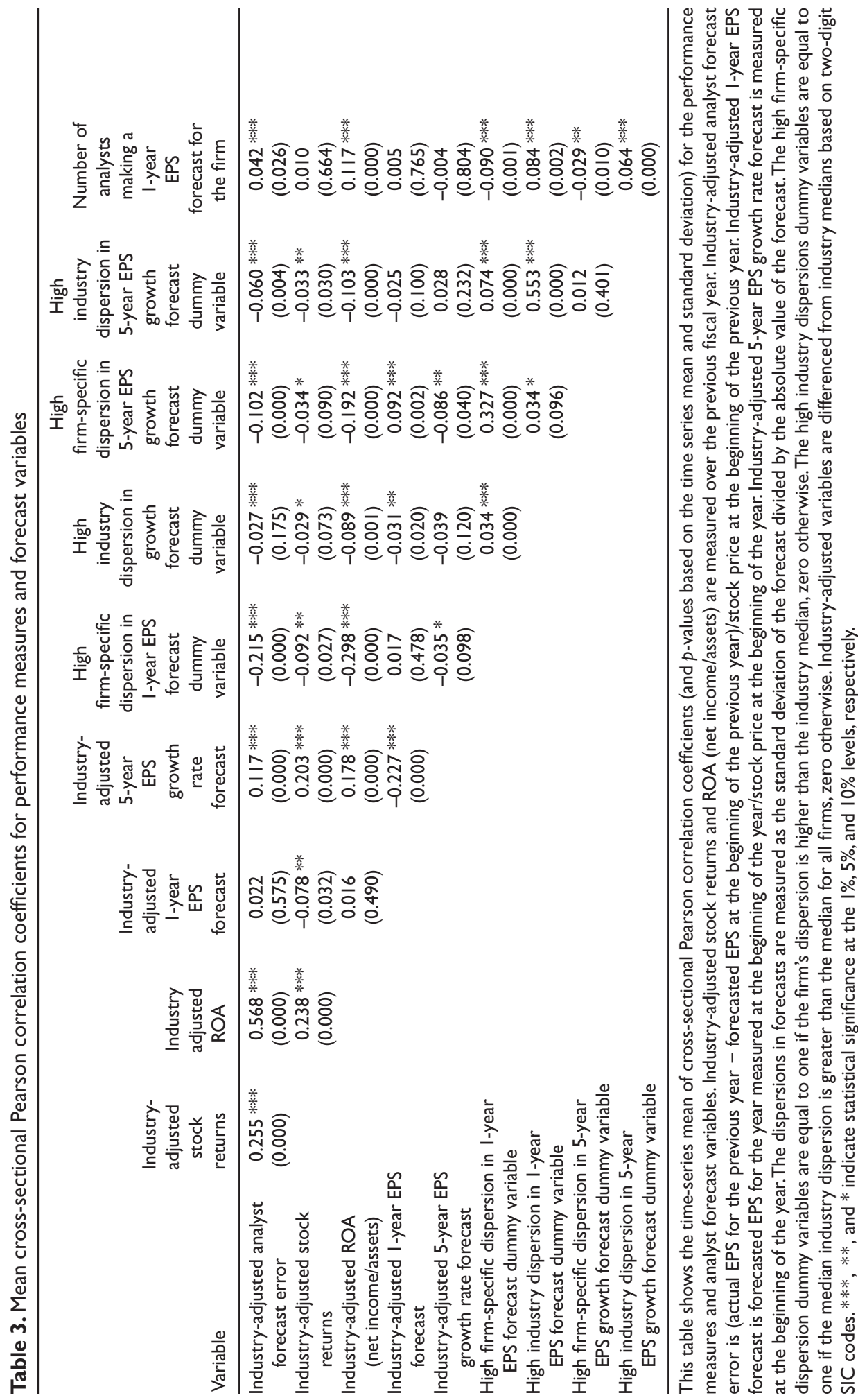


EPS growth rate forecast are negatively correlated. Although not shown in the table, we also note a negative correlation of -0.253 between firm size, as measured by the log of the number of firm employees, and the industry-adjusted 5-year EPS growth rate forecast. We also expect firm size and growth rates to have opposing effects on the likelihood of outside replacement. Given the relatively high correlations between some of the performance measures, our analysis may lack power due to multicollinearity. Therefore, we estimate alternative specifications of our model in Section 4.

\section{Determinants of CEO turnover and replacement choice}

Consistent with our expectations and arguments, the univariate evidence presented above suggests a significant relation between analyst forecast errors and CEO turnover as well as a significant relation between 5-year EPS growth rate expectations and the choice of replacement CEO. The evidence is not conclusive, however, and does not control for other factors likely to affect both the CEO turnover and replacement decisions. Further, we have not considered the potential interdependencies between the two decisions. We do not observe a board's preference for an outside candidate unless there is a CEO turnover. In addition, the CEO turnover decision may be influenced by the availability of a suitable replacement. Following Borokhovich et al. (1996), we examine the simultaneous nature of the CEO turnover and replacement decisions more formally by estimating the following bivariate probit model:

$$
\begin{array}{ll}
T_{i}^{*}=\beta^{\prime}{ }_{1} X_{1 i}+\varepsilon_{1 i^{\prime}} & T_{i}=1 \text { if } T_{i}^{*}>0, \quad 0 \text { otherwise, } \\
O_{i}^{*}=\beta^{\prime}{ }_{2} X_{2 i}+\varepsilon_{2 i}, & O_{i}=1 \text { if } O_{i}^{*}>0, \quad 0 \text { otherwise, }
\end{array}
$$

where $T_{i}^{*}$ and $O_{i}^{*}$ are linear functions of the variables that affect the probability of CEO turnover and the probability of an outside replacement, respectively. The residuals $\varepsilon_{1 i}$ and $\varepsilon_{2 i}$ are distributed as bivariate normal with correlation coefficient $\rho$. The observed forms of $T_{i}^{*}$ and $O_{i}{ }^{*}$ are the dichotomous $T_{i}$ and $O_{i}$, where $T_{i}$ is equal to one for firms that experience turnover in a given year, zero for firms that do not experience turnover in a given year, and $O_{i}$ is equal to one for outside appointments, zero for inside appointments. Note that $O_{i}$ is only observed when $T_{i}=1$, indicating a form of sample selectivity. We estimate (1) and (2) simultaneously using a full information maximum likelihood estimator that controls for the correlation in error terms of the two equations and the sample selectivity. Specifically, the log-likelihood function is

$$
\begin{aligned}
\log L= & \sum_{i, O i=1, T i=1} \log \Phi_{2}\left[\beta^{\prime}{ }_{1} X_{1 i^{\prime}} \beta^{\prime}{ }_{2} X_{2 i^{\prime}} \rho\right] \\
& +\sum_{i, O i=0, T i=1} \log \Phi_{2}\left[\beta^{\prime}{ }_{1} X_{1 i^{\prime}}-\beta^{\prime}{ }_{2} X_{2 i^{\prime}}-\rho\right]-\sum_{i, T i=0} \log \Phi_{1}\left[-\beta^{\prime}{ }_{1} X_{1 i}\right]
\end{aligned}
$$


where $\Phi_{2}$ is the bivariate standard normal cumulative distribution function and $\Phi_{1}$ is the univariate standard normal cumulative distribution function. ${ }^{21}$

Table 4 shows the results of estimating the bivariate probit model. Panel A of Table 4 shows the results for Equation (1), the turnover equation. Panel B of Table 4 shows the results for Equation (2), the outside replacement equation. All of the estimated models include year dummy variables, but the coefficients associated with these variables are not shown for brevity.22 Note that Model 1 in Panel A includes the same variables as Models 3 and 4 and that Model 2 includes the same variables as Model 5. The variation in the results of these models can be attributed to the differences in the variables that are included in Equation (2) of the bivariate probit model. It is worth noting, however, that the results for Equation (1) are largely invariant to the specification of Equation (2).

\subsection{Bivariate probit results for the likelihood of CEO turnover}

As shown in Panel A of Table 4, we find a much greater likelihood of turnover for older CEOs. In addition, the CEOs of large firms are more likely to experience turnover than their small firm counterparts. Both industry-adjusted ROA and the industry-adjusted analyst forecast errors are inversely related to the likelihood of CEO turnover in all of the model specifications. When all the performance variables are included (Model 6), the coefficient on industry-adjusted stock returns is not significant.

These results suggest that while the overall level of firm performance is inversely related to the likelihood of CEO turnover, the unexpected component of firm performance, as measured by industry-adjusted analyst forecast errors, also has a significant impact on the likelihood of CEO turnover. This is consistent with the argument that the board of directors distinguishes between firm performance and CEO performance by holding the CEO accountable for the firm's failure to meet earnings expectations.

Although both industry-adjusted ROA and the industry-adjusted analyst forecast errors are statistically significant in explaining the likelihood of CEO turnover, their economic significance is small. Other studies note that the incidence of CEO turnover is very low in even the worst performing firms. For example, Huson et al. (2001) find that the frequency of CEO turnover varies from approximately nine percent to 15 percent over four sub-sample periods between 1971 and 1994 for firms in the lowest quartile of accounting return performance. The rate of CEO turnover in the highest quartile of accounting return performance in their sample is only slightly lower, varying from approximately seven percent to 12 percent. Further, they estimate the implied probabilities of a forced turnover for their sample and find that the likelihood of a forced CEO turnover in a given year is only 2.64 percent greater in the lowest quartile of firm performance

21 See Greene (1997) for a detailed description of the bivariate probit methodology.

22 The results concerning the year dummy variables are consistent with the general increase in the likelihood of outside replacement in the years after 1992, as suggested by Table 1. 


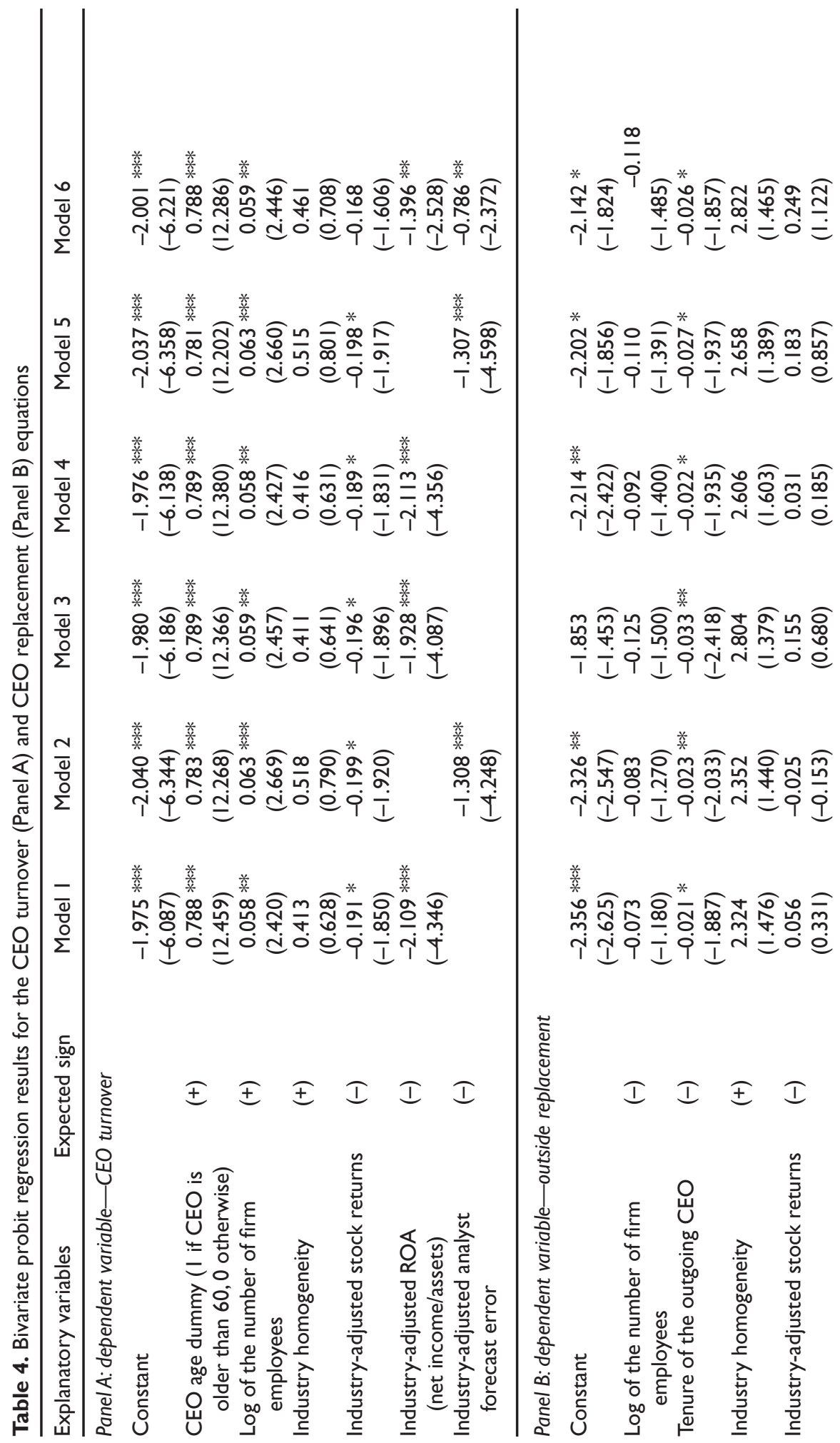




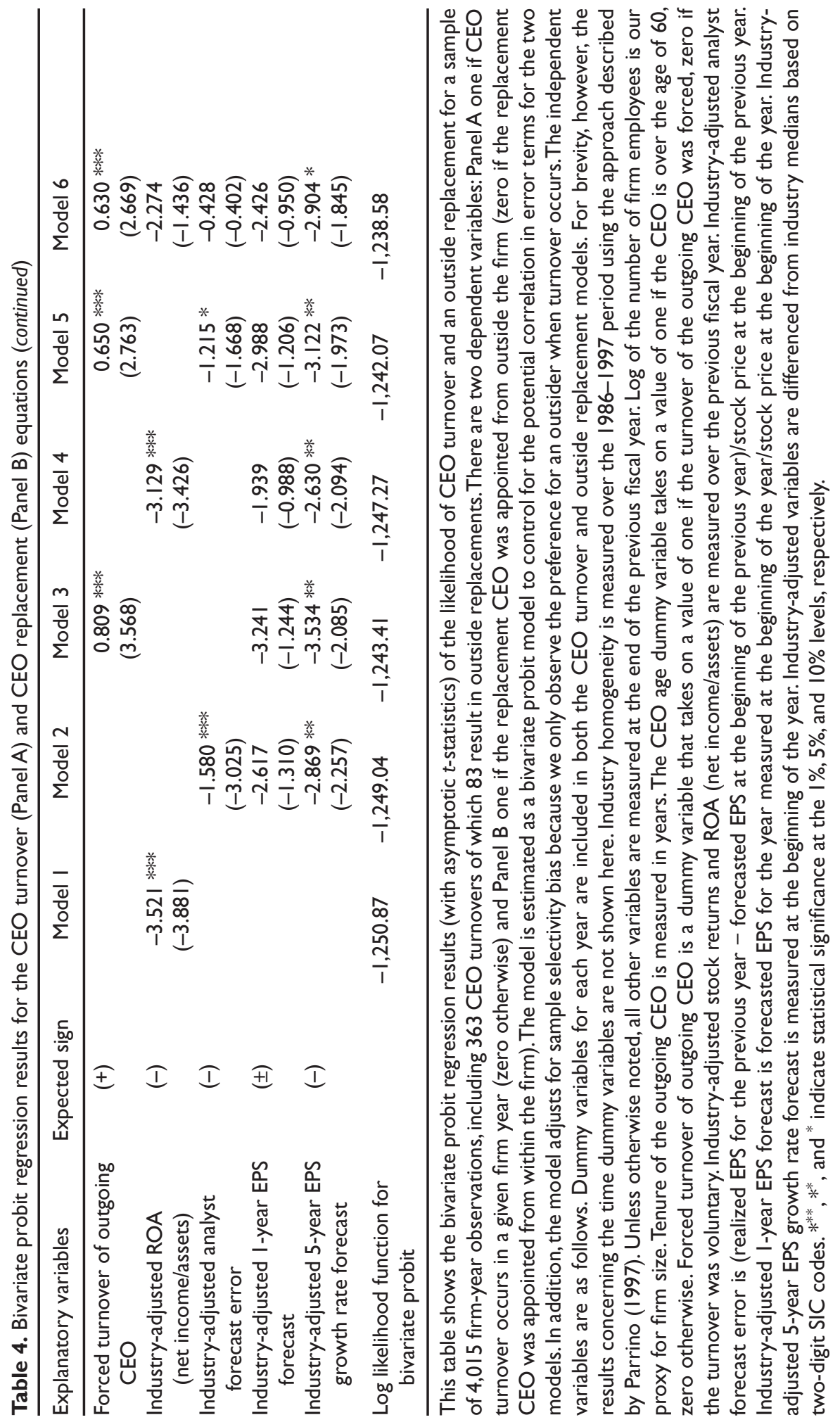


(industry-adjusted EBIT/assets) than in the highest quartile of firm performance over the 1989-1994 period. Consistent with these results, the implied probability of CEO turnover increases by 1.14 percent and 0.88 percent in our sample when the industry-adjusted ROA and industry-adjusted analyst forecast errors decline by one standard deviation, respectively. ${ }^{23}$

\subsection{Bivariate probit results for the likelihood of an outside replacement}

Panel B of Table 4 shows the results for Equation (2), the outside replacement equation, in the bivariate probit model. As expected, those firms in which the outgoing CEO has been in place for many years are less likely to appoint an outsider. The coefficient for the tenure of the outgoing CEO is negative and statistically significant in all the model specifications. Models 3, 5, and 6 include a forced-turnover dummy variable because Table 1 suggests an increased incidence of an outside appointment following a forced turnover. Consistent with previous studies (e.g., Agrawal et al., 2001), the coefficient for the forced-turnover dummy variable is consistently positive and statistically significant. This suggests that the board of directors is more likely to appoint an outside replacement after they have forced the removal of the previous CEO.

With the exception of industry-adjusted stock returns, the historical performance measures have the expected effect on the likelihood that an outside CEO is appointed, but the coefficients are not statistically significant when the forcedturnover variable is also included. This suggests that while historical performance may affect the likelihood of CEO turnover and the type of turnover, as found in other studies, it does not have a statistically significant impact on the choice of replacement CEO beyond its impact on the type of turnover.

As expected, the industry-adjusted 5-year EPS growth rate forecast is inversely related to the likelihood that an outsider is appointed CEO, suggesting that those firms with poor long-term earnings prospects are more likely to appoint an outsider. In addition, we find little evidence that outside replacement is motivated by poor past performance except to the extent that poor past performance is reflected in the board's decision to forcibly remove the previous CEO. Rather than reacting to poor performance by appointing an outside CEO, the evidence found here suggests that boards of directors appoint an outside CEO in an effort to change future earnings prospects.

23 The changes in the implied probability of CEO turnover are derived from the marginal effects of decreases in the industry-adjusted ROA and industry-adjusted analyst forecast errors in a univariate probit model that includes the variables shown in Model 6 of Panel A in Table 4. The reason we estimate the marginal effects using a univariate probit model is that the usual marginal effects calculated for a bivariate probit model considers the direct as well as the indirect impact of explanatory variables on the probabilities associated with the dependent variables. Because our bivariate probit model involves sample selectivity, however, the only marginal effects we can adequately determine are the marginal effects of the explanatory variables on the probability of an outside appointment conditional on observing a CEO turnover. 
Conditional on CEO turnover, the probability of an outside replacement increases by 6.57 percent when the industry-adjusted 5-year EPS growth rate declines by one standard deviation (6.65 percent). ${ }^{24}$ Given that only 22.9 percent of the appointments in our sample are outside appointments, a 6.57 percent increase in the probability of such appointments is economically meaningful, suggesting that poor long-term earnings prospects have an important impact on the likelihood of an outside appointment.

Consistent with our first and third hypotheses, the evidence presented in Table 4 indicates an inverse relation between analyst forecast errors and CEO turnover as well as an inverse relation between 5-year EPS growth rate expectations and the appointment of an outside CEO. To determine the robustness of our results, we re-estimate Model 6 from Table 4 using industry-adjusted EBIT-to-assets and industry-adjusted net operating cash flow-to-assets in place of industry-adjusted ROA. We find an inverse relation between analyst forecast errors and the likelihood of CEO turnover independent of the alternative performance measure used. Likewise, our results for outside replacement are qualitatively the same as those reported in Panel B of Table 4. Overall, our conclusions are robust to alternative firm performance measures and model specifications.

\subsection{Bivariate probit results including the dispersion of analyst forecasts}

To more formally analyze whether boards hold CEOs accountable for earnings estimates, we specify Model 6 from Table 4 to include controls for the dispersion in analyst forecasts. Following DeFond et al. (2002), we define the dispersion of analyst forecasts as dummy variables due to the skewness in the variable. Unlike Defond et al., however, we decompose the dispersion variable into its industry component and its firm-specific component. Specifically, we create two dummy variables: a dummy variable that is equal to one if the median industry dispersion measure is greater than the median for all firms, zero otherwise; and a dummy variable that is equal to one if the firm's dispersion measure is greater than the industry median, zero otherwise.

To determine whether the association between the likelihood of CEO turnover and analysts' forecast errors is related to analyst forecast dispersion, we also specify an interaction term between the forecast dispersion dummy variables and the analyst forecast error variable. Note that our total number of observations falls from 4,015 to 3,987 and the number of turnovers falls from 363 to 360 due to data limitations associated with the dispersion variables.

Panel A in Table 5 shows that there is a positive and significant relation between CEO turnover and the interaction between high firm-specific dispersion and industry-adjusted analyst forecast errors. Consistent with our second hypothesis, when firm-specific analyst forecast dispersion is high, analyst forecast errors

24 The marginal effects of the variables in Model 6, Panel B of Table 4 are conditional on CEO turnover. The effects are evaluated at the means of the explanatory variables across all observations. See Greene (1997) for a discussion of marginal effects in a bivariate probit model. 
Table 5. Bivariate probit regression results with the dispersion in analyst forecasts included

\begin{tabular}{|c|c|c|c|c|}
\hline \multirow{2}{*}{$\frac{\text { Explanatory variables }}{\text { Panel A: dependent variable-CEO turnover }}$} & Expected sign & \multirow[t]{2}{*}{ Model 7} & \multirow[t]{2}{*}{ Model 8} & \multirow[t]{2}{*}{ Model 9} \\
\hline & & & & \\
\hline Constant & & $\begin{array}{l}-2.295 * * * \\
(-7.749)\end{array}$ & $\begin{array}{l}-2.286 * * * \\
(-7.654)\end{array}$ & $\begin{array}{l}-2.27 I * * * \\
(-7.659)\end{array}$ \\
\hline $\begin{array}{l}\text { CEO age dummy ( }(1 \text { if CEO is } \\
\text { older than } 60,0 \text { otherwise) }\end{array}$ & $(+)$ & $\begin{array}{l}0.797 \text { *** } \\
(|2.18|)\end{array}$ & $\begin{array}{l}0.802 \text { *** } \\
(12.223)\end{array}$ & $\begin{array}{l}0.800 \text { *** } \\
(12.210)\end{array}$ \\
\hline Log of the number of firm & $(+)$ & $0.065 * * *$ & $0.065 * * *$ & $0.064 * * *$ \\
\hline employees & & $(2.655)$ & $(2.624)$ & $(2.6 \mid 8)$ \\
\hline Industry homogeneity & $(+)$ & $\begin{array}{l}0.410 \\
(0.607)\end{array}$ & $\begin{array}{l}0.473 \\
(0.705)\end{array}$ & $\begin{array}{c}0.477 \\
(0.733)\end{array}$ \\
\hline Industry-adjusted stock returns & $(-)$ & $\begin{array}{l}-0.152 \\
(-1.447)\end{array}$ & $\begin{array}{l}-0.154 \\
(-1.436)\end{array}$ & $\begin{array}{l}-0.155 \\
(-1.456)\end{array}$ \\
\hline $\begin{array}{r}\text { Industry-adjusted ROA } \\
\text { (net income/assets) }\end{array}$ & $(-)$ & $\begin{array}{l}-1.139 * * \\
(-2.035)\end{array}$ & $\begin{array}{l}-1.035 * \\
(-1.757)\end{array}$ & $\begin{array}{l}-1.049 * \\
(-1.816)\end{array}$ \\
\hline $\begin{array}{l}\text { Industry-adjusted analyst forecast } \\
\text { errors }\end{array}$ & $(-)$ & $\begin{array}{l}-0.876 \text { *** } \\
(-2.850)\end{array}$ & $\begin{array}{l}-3.218 * * * \\
(-2.983)\end{array}$ & $\begin{array}{l}-2.718 \text { *** } \\
(-3.008)\end{array}$ \\
\hline $\begin{array}{l}\text { High firm-specific dispersion in } \\
\text { I-year EPS forecast dummy variable }\end{array}$ & $( \pm)$ & $\begin{array}{l}0.058 \\
(0.875)\end{array}$ & $\begin{array}{c}0.072 \\
(1.063)\end{array}$ & $\begin{array}{c}0.073 \\
(1.086)\end{array}$ \\
\hline $\begin{array}{l}\text { High industry dispersion in I-year } \\
\text { EPS forecast dummy variable }\end{array}$ & $( \pm)$ & $\begin{array}{l}-0.005 \\
(-0.079)\end{array}$ & $\begin{array}{l}0.007 \\
(0.111)\end{array}$ & \\
\hline $\begin{array}{l}\text { High firm-specific dispersion } \times \text { industry- } \\
\text { adjusted analyst forecast errors }\end{array}$ & $(+)$ & & $\begin{array}{l}2.133 * * \\
(2.284)\end{array}$ & $\begin{array}{l}2.091 * * \\
(2.256)\end{array}$ \\
\hline $\begin{array}{l}\text { High industry dispersion } \times \text { industry- } \\
\text { adjusted analyst forecast errors }\end{array}$ & $(+)$ & & $\begin{array}{l}0.643 \\
(0.915)\end{array}$ & \\
\hline
\end{tabular}

Panel B: dependent variable—outside replacement

Constant

Log of the number of firm employees

Tenure of the outgoing CEO

Industry homogeneity

Industry-adjusted stock returns

Forced turnover of outgoing CEO

Industry-adjusted ROA (net income/assets)

Industry-adjusted analyst forecast errors

Industry-adjusted I-year EPS forecast

Industry-adjusted 5-year EPS growth rate forecast

High firm-specific dispersion in 5-year EPS growth forecast dummy variable

$\begin{array}{ccc}-1.334 & -1.121 & -1.212 \\ (-1.28 I) & (-0.959) & (-1.056) \\ -0.122 & -0.138 & -0.131 \\ (-1.438) & (-1.515) & (-1.479) \\ -0.026 * & -0.029 * & -0.029 * \\ (-1.783) & (-1.872) & (-1.889) \\ 2.103 & 2.559 & 2.793 \\ (1.084) & (1.243) & (1.418) \\ 0.315 & 0.414 * & 0.402 \\ (1.304) & (1.535) & (1.535) \\ 0.707 * * * & 0.736 * * * & 0.720 * * * \\ (2.824) & (2.925) & (2.867) \\ -2.060 & -2.570 & -2.586 \\ (-1.265) & (-1.410) & (-1.454) \\ -0.197 & 0.089 & 0.048 \\ (-0.182) & (0.072) & (0.040) \\ -2.365 & -2.035 & -2.201 \\ (-0.872) & (-0.710) & (-0.786) \\ -2.447 & 1.943 & 1.979 \\ (-1.458) & (0.632) & (0.778) \\ 0.321 & 0.219 & 0.223 \\ (1.596) & (1.052) & (1.093) \\ & & \end{array}$


Table 5 (continued).

\begin{tabular}{llccc}
\hline Explanatory variables & Expected sign & Model 7 & Model 8 & Model 9 \\
\hline High industry dispersion in 5-year EPS & $( \pm)$ & 0.103 & 0.102 & \\
$\quad$ growth forecast dummy variable & & $(0.560)$ & $(0.493)$ & \\
High firm-specific dispersion $\times$ industry- & $(+)$ & & -10.584 *** & -10.453 *** \\
$\quad$ adjusted 5-year growth rate forecast & & & $(-2.680)$ & $(-2.645)$ \\
High industry dispersion $\times$ industry- & $(+)$ & & 0.183 & \\
$\quad$ adjusted 5-year EPS growth rate forecast & & $(0.05 \mathrm{I})$ & \\
Log likelihood function for bivariate probit & $-1,230.88$ & $-1,223.08$ & $-1,223.72$ \\
\hline
\end{tabular}

This table shows the bivariate probit regression results (with asymptotic $t$-statistics) of the likelihood of CEO turnover and an outside replacement for a sample of 3,987 firm-year observations, including 360 CEO turnovers of which 83 result in outside replacements. We eliminated 28 of the original 4,015 firm-year observations, including three turnover observations, due to insufficient forecast dispersion data. There are two dependent variables: Panel $A$ one if CEO turnover occurs in a given firm year (zero otherwise) and Panel B one if the replacement CEO was appointed from outside the firm (zero if the replacement CEO was appointed from within the firm). The model is estimated as a bivariate probit model to control for the potential correlation in error terms for the two models. In addition, the model adjusts for sample selectivity bias because we only observe the preference for an outsider when turnover occurs. The independent variables are as follows. Dummy variables for each year are included in both the CEO turnover and outside replacement models. For brevity, however, the results concerning the time dummy variables are not shown here. Industry homogeneity is measured over the 1986-1997 period using the approach described by Parrino (1997). Unless otherwise noted, all other variables are measured at the end of the previous fiscal year. Log of the number of firm employees is our proxy for firm size. Tenure of the outgoing CEO is measured in years. The CEO age dummy variable takes on a value of one if the CEO is over the age of 60 , zero otherwise. Forced turnover of outgoing CEO is a dummy variable that takes on a value of one if the turnover of the outgoing CEO was forced, zero if the turnover was voluntary. Industry-adjusted stock returns and ROA (net income/assets) are measured over the previous fiscal year. Industry-adjusted analyst forecast error is (realized EPS for the previous year - forecasted EPS at the beginning of the previous year)/stock price at the beginning of the previous year. Industryadjusted I-year EPS forecast is forecasted EPS for the year measured at the beginning of the year/stock price at the beginning of the year. Industry-adjusted 5-year EPS growth rate forecast is measured at the beginning of the year.The dispersions in forecasts are measured as the minimum of 10 or the standard deviation of the forecast divided by the absolute value of the forecast. The high firm-specific dispersion dummy variables are equal to one if the firm's dispersion is higher than the industry median, zero otherwise. The high industry dispersions dummy variables are equal to one if the median industry dispersion is greater than the median for all firms, zero otherwise. Industryadjusted variables are differenced from industry medians based on two-digit SIC codes. $*^{* *}, *^{*}$, and * indicate statistical significance at the $1 \%, 5 \%$, and $10 \%$ levels, respectively.

have a weaker impact on the likelihood of CEO turnover. This suggests that analyst forecast errors are afforded less weight in the turnover decision when there is more uncertainty relative to other firms in the industry regarding earnings forecasts. Our evidence is consistent with DeFond et al. (2002) who find that dispersion in analysts' forecasts weakens the ability of the forecasts to explain the CEO pay-performance relation. ${ }^{25}$

25 find evidence of lower bonuses for CEOs missing consensus earnings forecasts. Our results suggest a more severe penalty of turnover if CEOs miss earnings forecasts when analysts' dispersion is low. 
The coefficients for the industry dispersion dummy variable and the interaction between the industry dispersion dummy variable and industry-adjusted analyst forecast errors are not significant. In results not shown, we estimate Models 7,8 , and 9 using one dummy variable based on whether the dispersion in analyst forecasts is greater than the median for all firms, and find insignificant results concerning this dispersion variable and the interaction between the dispersion variable and industry-adjusted forecast errors. ${ }^{26}$ Overall, these results suggest that relative uncertainty rather than total uncertainty affects the relation between industry-adjusted analyst forecast errors and CEO turnover. The implication is that analyst forecasts serve as a reasonable proxy for the board's CEO performance expectations and any deviation of firm performance from those expectations increases the likelihood of CEO turnover only when the dispersion associated with the firm's earnings forecast is less than the industry median.

To the extent that analyst forecast dispersion captures disagreement among analysts (and board members) regarding a firm's future earnings prospects, hypothesis four predicts that more dispersion in the 5-year EPS growth rate forecasts will be associated with a weaker signal regarding the soundness of the firm's policies and strategies. Similar to the dispersion in 1-year EPS forecasts, we define two dummy variables: a dummy variable that is equal to one if the median industry dispersion measure is greater than the median for all firms, zero otherwise; and a dummy variable that is equal to one if the firm's dispersion measure is greater than the industry median, zero otherwise.

Contrary to our fourth hypothesis, Models 8 and 9 in Panel B of Table 5 indicate that the negative relation between 5-year EPS growth rate forecasts and the likelihood of an outside appointment only holds when the firm-specific dispersion in analyst forecasts is high. The coefficient on the 5-year EPS growth rate forecast is not statistically significant while the coefficient on the interaction between the 5-year EPS growth rate forecast and firm-specific dispersion in the forecast is negative and statistically significant. ${ }^{27}$

The results in Panel B of Table 5 suggest that board members are more willing to make a significant change in firm leadership by appointing an outside CEO when the firm's industry-adjusted consensus long-term earnings forecast is pessimistic and there is greater firm-specific uncertainty about the forecast. Contrary to our expectations, when there is agreement among analysts about the firm's longterm earnings prospects, analysts' expectations have no significant impact on the

26 Similarly, when we substitute non-industry-adjusted performance variables for the industry-adjusted performance variables in Models 7, 8, and 9, the coefficients on the dispersion variable and the interaction between the dispersion variable and analyst forecast errors are insignificant. Also insignificant in the turnover equation is non-industry-adjusted ROA. Both stock returns and analyst forecast errors have negative and statistically significant coefficients.

27 Similar to the turnover equation, when we estimate Models 7, 8, and 9 using one dummy variable based on whether the dispersion in the 5-year forecast is greater than the median for all firms, we find insignificant results for the dispersion variable and the interaction between the dispersion variable and industry-adjusted 5-year EPS growth rate forecast. The 5-year EPS growth rate forecast is also no longer significant. 
likelihood of an outside replacement. Our interpretation of the results is that poor expectations combined with uncertainty increases the board of directors' willingness to make significant organizational change.

An alternative explanation is that dispersion increases prior to the appointment of an outside CEO because analysts anticipate a substantial change in firm leadership. According to this argument, we would expect that, after controlling for earnings expectations, one or more of the dispersion dummy variables would be statistically significant. Panel B of Table 5 shows that none of the dispersion dummy variables is statistically significant even when the interaction terms are excluded. We conclude that the dispersion measures do not reflect anticipation of an outside or inside replacement.

\subsection{Analyst following and forecast dispersion}

The results shown in Panel A of Table 5 indicate that firm-specific dispersion in 1-year EPS forecasts affects the relation between industry-adjusted analyst forecast errors and the likelihood of CEO turnover. Similarly, Panel B of Table 5 indicates that firm-specific dispersion in 5-year EPS growth rate forecasts affects the relation between industry-adjusted 5-year EPS growth rate forecasts and the likelihood of an outside replacement. An alternative explanation is that the firm-specific dispersion measure is capturing something other than abnormal uncertainty. For example, the firm-specific dispersion measure may be negatively related to the number of analysts following the firm even after controlling for the level of uncertainty associated with the firm's earnings. ' 28 The number of analysts following the firm rather than uncertainty concerning the firm's earnings forecast might be driving our results concerning the dispersion measure. To control for the number of analysts following the firm, we partition the sample into two samples based on the median number of analysts making a 1-year EPS forecast Note that sample firms may switch between partitions over the sample period. We then estimate the bivariate probit for the two partitions using the same specification as Model 9. 29

The Model 10 results shown in Panel A of Table 6 are consistent with the results shown in Table 5. Because Model 10 is estimated using only those observations where the number of analysts following the firm is less than or equal to the median, the findings suggest that the results shown in Table 5 are not driven by the number of analysts following the firm. Interestingly, the Model 11 results shown in Panel A indicate that analyst forecast errors have a significant impact on the likelihood of CEO turnover regardless of the level of uncertainty associated with the forecast in those observations where the number of analysts is

28 The number of analysts following the firm is negatively correlated with both the firm-specific dispersion in 1-year analyst forecast dummy variable $(-0.090)$ and the firm-specific dispersion in 5year analyst forecast errors dummy variable $(-0.026)$.

29 We partition the sample based on the number of analysts making a 1-year forecast rather than the number making a 5-year forecast because the 5-year forecast only enters the analysis directly for those firms experiencing a turnover. The correlation between the number of analysts making a 1year forecast and the number making a 5-year forecast is very high (0.827). 
greater than the median. These results suggest that if a large number of analysts are following the firm, then managers are held accountable for meeting earnings expectations even if there is disagreement among analysts concerning the forecast. This is consistent with the argument that analysts and other commentators have forced corporate boards to become more active and independent to avoid the potential for adverse publicity and a resulting decline in firm value (Lowenstein, 1996) and Lowenstein, 1999).

Table 6. Bivariate probit regression results by analyst following

\begin{tabular}{|c|c|c|c|}
\hline Explanatory variables & $\begin{array}{l}\text { Expected } \\
\text { sign }\end{array}$ & $\begin{array}{c}\text { Model } 10 \\
\text { (\# analysts } \leq \text { median) }\end{array}$ & $\begin{array}{c}\text { Model II } \\
(\# \text { analysts }>\text { median })\end{array}$ \\
\hline \multicolumn{4}{|l|}{ Panel A: dependent variable-CEO turnover } \\
\hline Constant & & $\begin{array}{l}-2.194 * * * \\
(-4.527)\end{array}$ & $\begin{array}{l}-2.118 * * * \\
(-4.279)\end{array}$ \\
\hline $\begin{array}{l}\text { CEO age dummy ( } I \text { if } C E O \text { is older } \\
\text { than } 60,0 \text { otherwise) }\end{array}$ & $(+)$ & $\begin{array}{l}0.669 * * * \\
(6.700)\end{array}$ & $\begin{array}{l}0.963 * * * \\
(9.624)\end{array}$ \\
\hline Log of the number of firm employees & $(+)$ & $\begin{array}{c}0.041 \\
(0.95 I)\end{array}$ & $\begin{array}{c}0.063 \\
(1.629)\end{array}$ \\
\hline Industry homogeneity & $(+)$ & $\begin{array}{c}0.086 \\
(0.077)\end{array}$ & $\begin{array}{l}1.080 \\
(1.183)\end{array}$ \\
\hline Industry-adjusted stock returns & $(-)$ & $\begin{array}{l}-0.158 \\
(-1.001)\end{array}$ & $\begin{array}{l}-0.148 \\
(-0.805)\end{array}$ \\
\hline Industry-adjusted ROA (net income/assets) & $(-)$ & $\begin{array}{l}-1.852 * * \\
(-2.12 \mid)\end{array}$ & $\begin{array}{l}-0.211 \\
(-0.200)\end{array}$ \\
\hline Industry-adjusted analyst forecast errors & $(-)$ & $\begin{array}{l}-2.740 * \\
(-1.890)\end{array}$ & $\begin{array}{l}-3.089 * * * \\
(-2.819)\end{array}$ \\
\hline $\begin{array}{l}\text { High firm-specific dispersion in I-year } \\
\text { EPS forecast dummy variable }\end{array}$ & $( \pm)$ & $\begin{array}{c}0.057 \\
(0.530)\end{array}$ & $\begin{array}{c}0.083 \\
(0.827)\end{array}$ \\
\hline $\begin{array}{l}\text { High firm-specific dispersion } \times \text { industry- } \\
\text { adjusted analyst forecast errors }\end{array}$ & $(+)$ & $\begin{array}{l}2.559 * \\
(1.715)\end{array}$ & $\begin{array}{c}1.640 \\
(1.303)\end{array}$ \\
\hline Number of observations & & 2,124 & 1,863 \\
\hline Number of turnovers & & 167 & 193 \\
\hline \multicolumn{4}{|l|}{ Panel B: dependent variable_-outside replacement } \\
\hline Constant & & $\begin{array}{c}-2.381 \\
(-1.209)\end{array}$ & $\begin{array}{l}-0.120 \\
(-0.057)\end{array}$ \\
\hline Log of the number of firm employees & $(-)$ & $\begin{array}{c}-0.012 \\
(-0.078)\end{array}$ & $\begin{array}{c}-0.237 \\
(-1.336)\end{array}$ \\
\hline Tenure of the outgoing CEO & $(-)$ & $\begin{array}{c}-0.041 \\
(-1.215)\end{array}$ & $\begin{array}{c}-0.027 \\
(-1.049)\end{array}$ \\
\hline Industry homogeneity & $(+)$ & $\begin{array}{c}3.452 \\
(0.834)\end{array}$ & $\begin{array}{c}3.204 \\
(1.008)\end{array}$ \\
\hline Industry-adjusted stock returns & $(-)$ & $\begin{array}{c}0.210 \\
(0.439)\end{array}$ & $\begin{array}{c}0.792 \\
(1.378)\end{array}$ \\
\hline Forced turnover of outgoing CEO & $(+)$ & $\begin{array}{c}0.500 \\
(1.325)\end{array}$ & $\begin{array}{l}1.036 * * \\
(2.161)\end{array}$ \\
\hline Industry-adjusted ROA (net income/assets) & $(-)$ & $\begin{array}{c}-1.884 \\
(-0.695)\end{array}$ & $\begin{array}{c}-5.601 \\
(-1.463)\end{array}$ \\
\hline
\end{tabular}


Table 6 (continued).

\begin{tabular}{lccc}
\hline Explanatory variables & $\begin{array}{c}\text { Expected } \\
\text { sign }\end{array}$ & $\begin{array}{c}\text { Model I0 } \\
\text { (\# analysts } \leq \text { median) }\end{array}$ & $\begin{array}{c}\text { Model II } \\
\text { \# analysts }>\text { median) }\end{array}$ \\
\hline Industry-adjusted analyst forecast errors & $(-)$ & -0.02 I & 1.394 \\
& & $(-0.012)$ & $(0.403)$ \\
Industry-adjusted I-year EPS forecast & $( \pm)$ & -3.182 & -1.128 \\
& & $(-0.682)$ & $(-0.184)$ \\
Industry-adjusted 5-year EPS growth & $(-)$ & 1.923 & 8.636 \\
$\quad$ rate forecast & & $(0.505)$ & $(1.010)$ \\
High firm-specific dispersion in 5-year & $( \pm)$ & 0.362 & -0.027 \\
$\quad$ EPS growth forecast dummy variable & & $(0.936)$ & $(-0.069)$ \\
High firm-specific dispersion $\times$ industry- & $(+)$ & -7.748 & $-20.966 *$ \\
$\quad$ adjusted 5-year growth rate forecast & & $(-1.181)$ & $(-1.933)$ \\
Number of observations & & 2,124 & 1,863 \\
Number of turnovers & & 167 & 193 \\
Number of outside appointments & & 47 & 36 \\
Log likelihood function for bivariate probit & & -605.29 & -593.33 \\
\hline
\end{tabular}

This table shows the bivariate probit regression results (with asymptotic $t$-statistics) with the sample partitioned by the number of analysts making I-year EPS forecasts for the firm in a given year. The tables indicate the likelihood of CEO turnover and an outside replacement for a sample of 3,987 firm-year observations, including 360 CEO turnovers of which 83 result in outside replacements. We eliminated 28 of the original 4,0I5 firm-year observations, including three turnover observations, due to insufficient forecast dispersion data. There are two dependent variables: Panel $A$ one if CEO turnover occurs in a given firm year (zero otherwise) and Panel B one if the replacement CEO was appointed from outside the firm (zero if the replacement CEO was appointed from within the firm). The model is estimated as a bivariate probit model to control for the potential correlation in error terms for the two models. In addition, the model adjusts for sample selectivity bias because we only observe the preference for an outsider when turnover occurs. The independent variables are as follows. Dummy variables for each year are included in both the CEO turnover and outside replacement models. For brevity, however, the results concerning the time dummy variables are not shown here. Industry homogeneity is measured over the 1986-1997 period using the approach described by Parrino (1997). Unless otherwise noted, all other variables are measured at the end of the previous fiscal year. Log of the number of firm employees is our proxy for firm size. Tenure of the outgoing CEO is measured in years. The CEO age dummy variable takes on a value of one if the CEO is over the age of 60 , zero otherwise. Forced turnover of outgoing CEO is a dummy variable that takes on a value of one if the turnover of the outgoing CEO was forced, zero if the turnover was voluntary. Industry-adjusted stock returns and ROA (net income/assets) are measured over the previous fiscal year. Industry-adjusted analyst forecast error is (realized EPS for the previous year - forecasted EPS at the beginning of the previous year)/stock price at the beginning of the previous year. Industry-adjusted I-year EPS forecast is forecasted EPS for the year measured at the beginning of the year/stock price at the beginning of the year. Industry-adjusted 5-year EPS growth rate forecast is measured at the beginning of the year.The dispersions in forecasts are measured as the minimum of 10 or the standard deviation of the forecast divided by the absolute value of the forecast. The high firm-specific dispersion dummy variables are equal to one if the firm's dispersion is higher than the industry median, zero otherwise. The high industry dispersions dummy variables are equal to one if the median industry dispersion is greater than the median for all firms, zero otherwise. Industry-adjusted variables are differenced from industry medians based on two-digit SIC codes. $*^{* *}, *^{*}$, and ${ }^{*}$ indicate statistical significance at the $1 \%, 5 \%$, and $10 \%$ levels, respectively. 
The results concerning the outside replacement decision are weaker when estimated for the partitioned sample. In fact, none of the explanatory variables are statistically significant for Model 10 in Panel B of Table 6. Only the forced-turnover variable and the interaction between high firm-specific dispersion in the 5year EPS growth rate forecast and the forecast itself are statistically significant for Model 11 in Panel B. This can be attributed, in part, to the small number of turnover observations in each partition and the relatively large number of explanatory variables, which includes year dummy variables.

Overall, the results based on the partitioned sample suggest that 1-year EPS forecasts act as a reasonable proxy for performance standards used in CEO turnover decisions when there is little uncertainty associated with the forecast, as compared to industry peers, or when there are a relatively large number of analysts following the firm. Conditional on turnover, the likelihood of an outside replacement is greater when 5-year EPS forecasts are low relative to industry peers, there is disagreement among analysts concerning the forecast, and there is a relatively large number of analysts following the firm.

\section{Conclusion}

Using a sample of 4,015 firm-year observations that include 363 CEO turnovers that occurred during the 1986-1997 period, we find an increased likelihood of CEO turnover when the CEO is older than 60 years of age and the firm is relatively large. Controlling for these factors and measures of firm performance, we also find an inverse relation between the likelihood of CEO turnover and the industry-adjusted 1-year analyst forecast errors when there is agreement (less dispersion) among analysts regarding 1-year earnings forecasts or a relatively large number of analysts follow the firm. We argue that the analyst forecast error is capturing the deviation from performance expectations rather than simply overall firm performance and that the board of directors uses expectations as part of the criteria in evaluating CEO performance.

For the firms that experience CEO turnover, we find an increased likelihood of an outside replacement when the outgoing CEO had a relatively short tenure and the outgoing CEO was forced to resign. Controlling for these factors and measures of firm performance, we find an inverse relation between industry-adjusted 5-year EPS growth rate forecasts and the likelihood that an outsider is appointed CEO. However, we find that the negative relation between the growth rate forecast and the likelihood of an outside replacement applies only to those firms with a high level of firm-specific dispersion in the forecast. This suggests that the 5year EPS growth rate forecast helps explain the CEO replacement decision only when there is uncertainty among analysts (and presumably board members) regarding the firm's future growth prospects. Overall, the implication is that the decision to replace an outgoing CEO with an outside candidate is, in general, an attempt to improve the long-range earnings prospects for the firm rather than a reaction to poor historical performance. 


\section{References}

Aboody and Kasznik (2000) D D. Aboody and R. Kasznik, CEO stock option awards and the timing of corporate voluntary disclosures. Journal of Accounting and Economics 29 (2000), pp. 73-100.

Agrawal et al. (2001) A A. Agrawal, C. R. Knoeber, and T. Tsoulouhas, CEO succession: insiders versus outsiders. University of Alabama, Working Paper, 2001.

Atiase and Bamber (1994) $>$ R. K. Atiase and L. S. Bamber, Trading volume reactions to annual accounting earnings announcements. Journal of Accounting and Economics $\mathbf{1 7}$ (1994), pp. 309-329.

Barro and Barro (1990) $>$ J. R. Barro and R. J. Barro, Pay, performance, and turnover of bank CEOs. Journal of Labor Economics 8 (1990), pp. 448-481.

Bartov et al. (2002) - E. Bartov, D. Givoly, and C. Hayn, The rewards to meeting or beating earnings expectations. Journal of Accounting and Economics 33 (2002), pp. 173-204.

Blackwell et al. (1994) $>$ D. W. Blackwell, J. A. Brickley, and M. Weisbach, Accounting information and internal performance evaluation: evidence from Texas banks. Journal of Accounting and Economics 17 (1994), pp. 331-358.

Borokhovich et al. (1996) K. A. Borokhovich, R. Parrino, and T. Trapani, Outside directors and CEO selection. Journal of Financial and Quantitative Analysis 31 (1996), pp. 337-355.

Coughlan and Schmidt (1985) $\triangleright$ A. T. Coughlan and R. M. Schmidt, Executive compensation, management turnover, and firm performance: an empirical investigation. Journal of Accounting and Economics 7 (1985), pp. 43-66.

DeFond and Park (1999) - M. L. DeFond and C. W. Park, The effect of competition on CEO turnover. Journal of Accounting and Economics 27 (1999), pp. 35-56.

DeFond et al. (2002) $>$ M. L. DeFond, S. R. Matsunaga, and C. W. Park, An empirical assessment of the consensus analyst forecast proxy for CEO performance standards. University of Southern California, Working Paper, 2002.

Denis and Denis (1995) D D. J. Denis and D. K. Denis, Performance changes following top management dismissals. Journal of Finance 50 (1995), pp. 1029-1057.

Engel et al. (2002) E. Engel, R. M. Hayes, and X. Wang, 2003. CEO turnover and properties of accounting information. Journal of Accounting and Economics 136(1-3).

Farrell and Whidbee (2002) $>$ K. A. Farrell and D. A. Whidbee, Monitoring by the financial press and forced CEO turnover. Journal of Banking and Finance 26 (2002), pp. 2249-2276.

Gilson (1989) - S. C. Gilson, Management turnover and financial distress. Journal of Financial Economics 25 (1989), pp. 241-262.

Ginzel et al. (1992) - L. E. Ginzel, R. M. Kramer, and R. I. Sutton, Organizational impression management as a reciprocal influence process: the neglected role of the organizational audience. Research in Organizational Behavior 15 (1992), pp. 227-266.

Greene (1997) W. Greene, Econometric Analysis. (3rd Edition. ed. ), Prentice-Hall, Englewood Cliffs, NJ (1997).

Goyal and Park (2002) V V. K. Goyal and C. W. Park, Board leadership structure and CEO turnover. Journal of Corporate Finance 8 (2002), pp. 49-66.

Healy and Wahlen (1999) $>$ P. M. Healy and J. M. Wahlen, A review of the earnings management literature and its implications for standard setting. Accounting Horizons 134 (1999), pp. 365-383. 
Hermalin and Weisbach (1998) $>$ B. E. Hermalin and M. S. Weisbach, Endogenously chosen boards of directors and their monitoring of the CEO. The American Economic Review 88 (1998), pp. 96-118.

Holmstrom (1979) $>$ B. Holmstrom, Moral hazard and observability. Bell Journal of Economics 10 (1979), pp. 74-91.

Huson et al. (2001) $>$ M. R. Huson, R. Parrino, and L. Starks, Internal monitoring mechanisms and CEO turnover: a long-term perspective. Journal of Finance 56 (2001), pp. 2265-2297.

Kasznik (1999) $>$ R. Kasznik, On the association between voluntary disclosure and earnings management. Journal of Accounting Research 70 (1999), pp. 57-81.

Kasznik and Lev (1995) $>$ R. Kasznik and B. Lev, To warn or not to warn: management disclosures in the face of an earnings surprise. The Accounting Review 70 (1995), pp. 113-134.

Khanna and Poulsen (1995) N N. Khanna and A. B. Poulsen, Managers of financially distressed firms: villains or scapegoats?. Journal of Finance 50 (1995), pp. 919-939.

Lambert and Larcker (1987) $>$ R. A. Lambert and D. F. Larcker, An analysis of the use of accounting and market measures of performance in executive compensation contracts. Journal of Accounting Research 25 (1987), pp. 85-125.

Lowenstein (1996) - L. Lowenstein, Financial transparency and corporate governance: you manage what you measure. Columbia Law Review 96 (1996), pp. 1335-1362.

Lowenstein (1999) $>$ L. Lowenstein, Corporate governance and the voice of the paparazzi. The Center for Law and Economic Studies Working Paper No. 132, 1999.

Matsunaga and Park (2001) $>$ S. R. Matsunaga and C. W. Park, The effect of missing a quarterly earnings benchmark on the CEO's annual bonus. The Accounting Review 76 (2001), pp. 313-332.

Murphy and Zimmerman (1993) - K. Murphy and J. L. Zimmerman, Financial performance surrounding CEO turnover. Journal of Accounting and Economics 16 (1993), pp. 273-315.

Parrino (1997) $>$ R. Parrino, CEO turnover and outside succession: a cross-sectional analysis. Journal of Financial Economics 46 (1997), pp. 165-197.

Payne and Robb (2000). J. L. Payne and S. W. G. Robb, Earnings management: the effect of ex ante earnings expectations. Journal of Accounting, Auditing and Finance 15 (2000), pp. 371-392.

Puffer and Weintrop (1991). S. M. Puffer and J. B. Weintrop, Corporate performance and CEO turnover: the role of performance expectation. Administrative Science Quarterly 36 (1991), pp. 1-19.

Skinner (1997) D D. J. Skinner, Earnings disclosures and stockholder lawsuits. Journal of Accounting and Economics 23 (1997), pp. 249-282.

Sloan (1993) $>$ R. G. Sloan, Accounting earnings and top executive compensation. Journal of Accounting and Economics 16 (1993), pp. 55-100.

Soffer et al. (2000) L. C. Soffer, S. R. Thiagarajan and B. R. Walther, Earnings preannouncement strategies. Review of Accounting Studies 26 (2000), pp. 5-26.

Warner et al. (1988) > J. B. Warner, R. L. Watts and K. Wruck, Stock prices and top management changes. Journal of Financial Economics 20 (1988), pp. 461-492.

Weisbach (1988) - M. S. Weisbach, Outside directors and CEO turnover. Journal of Financial Economics 20 (1988), pp. 431-460. 